\title{
C Peptide
}

National Cancer Institute

\section{Source}

National Cancer Institute. CPeptide. NCI Thesaurus. Code C94608.

C peptide (31 aa, $\sim 3 \mathrm{kDa}$ ) is encoded by the human INS gene. This protein is involved in both signal transduction and the modulation of blood flow. 